Vol.45, n. 4 : pp. 423-429, December 2002

ISSN 1516-8913 Printed in Brazil

\title{
Influence of Post Harvest Processing Conditions on Yield and Quality of Ground Turmeric (Curcuma longa L.)
}

\author{
Maria Lúcia A. Bambirra, Roberto G. Junqueira and Maria Beatriz A. Glória \\ Departamento de Alimentos; Faculdade de Farmácia; Universidade Federal de Minas Gerais; Av. Olegário Maciel \\ 2360; 30180-112; Belo Horizonte - MG - Brazil
}

\begin{abstract}
Studies were carried out to evaluate the influence of post harvest processing conditions on yield and quality of ground turmeric. Rhizomes were peeled, cooked (autoclave or immersion) in water or alkaline media, sliced, dehydrated, ground, sieved, packaged in polyethylene bags and stored for 60 days at room temperature. Yields ranged from 9.84 to $14.51 \mathrm{~g}$ of powder/100 $\mathrm{g}$ of rhizome with moisture varying from 8.84 to $9.86 \mathrm{~g} / 100 \mathrm{~g}$. Peel removal caused $30 \%$ mass loss but the powder obtained had higher intensity of yellow and red. Cooking caused a reduction in dehydration time and provided a powder with lower moisture content, higher levels of curcuminoid pigments and higher Hunter CIE $L^{*}, a^{*}$ and $b^{*}$ values. Cooking by immersion provided higher quality powder compared to autoclave. Use of alkaline media resulted in a product with lower curcuminoid content, and higher intensity of yellow. There was no change in pigment and colour characteristics during storage.
\end{abstract}

Key words: Turmeric, curcuminoid pigments, natural colorants, processing

\section{INTRODUCTION}

Turmeric (Curcuma longa L.), plant of the Zingiberaceae family, is known as haldi, gelbwurzel, safran des Indes, dilau, cúrcuma, açafrão, yellow or golden ginger. The rhizomes of this plant, when dried and ground, provide a yellow and flavorful powder, used for centuries as a natural coloring agent in food, cosmetics and textiles, as a flavoring compound and also as insect repellent and as an Indian medicine (Govindarajan, 1980). Recently, it has been valued worldwide as a functional food, due to its health promoting properties. Turmeric has been used as antioxidant, digestive, anti-microbial, antiinflammatory and anti-carcinogenic agent. It lowers total cholesterol levels. It is also efficient in the treatment of circulatory problems, liver diseases, dermatological disorders and in blood purification (Guimarães, 1987; Srinivas et al., 1992; Hallagan et al., 1995; Osawa et al., 1995; Semwal et al., 1997).

Turmeric has the advantage of not requiring special cultural practices; it presents good productivity (20 ton/hectare) and contains on average $6 \%$ of curcuminoid pigments and $5 \%$ of essential oils (Nunes, 1989). Brazil has favorable conditions for turmeric cultivation, where its production is reaching special place after annatto (Bixa orellana L.). However, there is need to develop processing technology in order to obtain products of added value and good quality. Studies on the effect of post-harvest treatment and processing on the quality of ground turmeric have

\footnotetext{
* Author for correspondence
} 
been performed (Govindarajan, 1980; Sampathu et al., 1988). Conventional processing of turmeric in Brazil consists of slicing the rhizome, sun drying and grinding. According to Govindarajan (1980), the common practice in India is to boil the rhizome in alkaline media prior to dehydration. However, there are controversies with respect to the importance of cooking the rhizomes in water or alkaline solution prior to drying and its influence on the levels of curcuminoid pigments and on the color of ground turmeric (Sampathu et al., 1988). Therefore, studies are necessary to investigate the role of different processing steps on the quality of ground turmeric. Another important aspect would be the search for technology capable of improving stability of curcuminoid pigments, since previous studies have demonstrated the sensibility of pigments to oxygen, light and alkaline $\mathrm{pH}$ (Tonnesen \& Karlsen, 1985b; Souza et al., 1997).

This study was undertaken to evaluate the effect of cooking on the quality of ground turmeric. The specific objectives were to investigate the influence of different processing conditions on yield, on curcuminoid pigments and on color characteristics of ground turmeric, and also to investigate the stability of curcuminoid pigments in ground turmeric during storage for 60 days.

\section{MATERIAL AND METHODS}

Mature fresh turmeric (Curcuma longa L) rhizomes were provided by EMATER-MG (Empresa de Assistência Técnica e Extensão Rural do Estado de Minas Gerais) from Patos de Minas, State of Minas Gerais, Brazil. Immediately after harvest, the rhizomes were transported to the Food Biochemistry Laboratory of the Pharmacy College at the Federal University of Minas Gerais (UFMG). Curcumin (Merck, Darmstadt, Germany) was used as standard.

Processing of turmeric. The rhizomes were washed, selected, dried with paper towel, homogenized and divided into three lots of $15 \mathrm{~kg}$ each. The lots were processed on distinct consecutive days. Each lot was divided into five smaller lots (ca. $3 \mathrm{~kg}$ ), each one being submitted to a different processing condition. One lot was not submitted to blanching (C). Two lots were cooked in boiling water ( $9 \mathrm{~L}$ water $/ 3 \mathrm{~kg}$ rhizome) for 90 minutes, the first in water $(\mathrm{CW})$ and the second in alkaline water containing $0.1 \%$ sodium bicarbonate at $\mathrm{pH} 8.6(\mathrm{CA})$. The other two lots were cooked in a retort at $121^{\circ} \mathrm{C}$ for 40 minutes, one lot with peel (RP) and the other without peel (RNP). The rhizomes were sliced longitudinally and dried at $60 \pm 2{ }^{\circ} \mathrm{C}$. The dried rhizomes were ground and sieved (42 mesh). The sieved powder was packaged in polyethylene bags removing excess air before sealing and stored at room temperature $\left(25 \pm 1^{\circ} \mathrm{C}\right)$, exposed to day and artificial fluorescent light. At ten days intervals two samples of each treatment were collected for analysis.

Levels of curcuminoid pigments. The levels of curcuminoid pigments were determined according to Takahashi (1987). Pigments were extracted by reflux with $95 \%$ ethanol for 150 minutes, filtered and quantified at $425 \mathrm{~nm}$ on a UV-VIS $160 \mathrm{~A}$ Shimadzu spectrophotometer (Kyoto, Japan). The concentration of the pigments was calculated by a standard curve. The results were reported in grams of curcuminoid pigments expressed as curcumin.

Moisture content. The moisture content of the samples was determined by dehydration at $105^{\circ} \mathrm{C}$ for 8 hours (Souza \& Glória, 1998).

Color characteristics. Hunter CIE $L^{*} a^{*} b^{*}$ characteristics were determined using a ColorQuest II colorimeter (HunterLab, Reston, Virginia, USA). Samples were placed in $1 \mathrm{~cm}$ pathlength optical glass cell and color parameters were measured in duplicate under total transmission mode, using illuminant D 65 and 10 degree observer angle.

Statistical analysis. The split-plot experimental design was used (time $=$ parcels, processing condition $=$ subparcels). The results obtained were submitted to analysis of variance and the means were compared by Duncan test at 5\% of probability (Gomes, 1990).

\section{RESULTS AND DISCUSSION}

Influence of processing on the yield and dehydration time of ground turmeric. The mass balance of turmeric during processing indicated that removal of the peel caused 30\% loss (Table 1). Cooking under immersion in water $(\mathrm{CW})$ and 
alkaline solution (CA) caused 3\% increase in weight, indicating water absorption by turmeric during cooking. There was mass loss for rhizomes submitted to retort processing (RP and RNP). Such a behavior during retorting could be explained by the flash effect. According to Mafart (1994), retort cooling after pressure-cooking takes place due to a drastic pressure drop. During depressurization, there is a fast evaporation, which causes water loss by the food, especially if it is not packed. As indicated on Table 1, the loss of mass by the rhizome without peel (RNP) was higher than for turmeric with peel (RP). This result indicates that the peel protected the rhizome, reducing weigh loss during retort process.

Table 1 - Influence of different types of processing on mass, yield, dehydration time and moisture content of ground turmeric

\begin{tabular}{cccccc}
\hline Parameters & \multicolumn{5}{c}{ Mean values for the treatments } \\
\cline { 2 - 6 } & $\mathrm{C}$ & RNP & RP & CW & CA \\
\hline Percent of peel & - & 30.1 & - & - & - \\
g/100 g (\% CV) & & $(1.8)$ & & 104 & 103 \\
Yield after cooking & 100 & 99.8 & 96.5 & 6 & 6 \\
Mean drying time (days) & 7 & 6 & 6 & $12.28^{\mathrm{ab}}$ & $12.16^{\mathrm{ab}}$ \\
Yield (g/100 g) & $13.46^{\mathrm{a}}$ & $9.84^{\mathrm{b}}$ & $14.51^{\mathrm{a}}$ & $(19)$ & $(8,8)$ \\
(\% CV) & $(14)$ & $(14)$ & $(4.8)$ & $8.84^{\mathrm{b}}$ & $9.15^{\mathrm{ab}}$ \\
Moisture content & $9.86^{\mathrm{a}}$ & $9.20^{\mathrm{ab}}$ & $8.93^{\mathrm{b}}$ & $(8.81)$ & $(10.32)$ \\
g/100 g (\% CV) & $(4.77)$ & $(7.59)$ & $(8.83)$ &
\end{tabular}

${ }^{1} \mathrm{C}$ - control (no heat treatment); RNP - retort cooking with no peel; RP - retort cooking with peel; CW - cooking in water; CA cooking in alkaline water. Mean values (CV - coefficient of variation) with the same superscript $(\mathrm{ab})$ in the same line, do not differ statistically (Duncan test, $\mathrm{p} \leq 0.05$ ).

Even though CW and CA samples gained weight after cooking, dehydration time and final moisture content were not affected. With respect to the time required for dehydration, the control sample (C) took longer to dry -7 days compared to the ones that had undergone blanching (6 days). Similar results were found by Govindarajan (1980) and Sampathu et al. (1988), who reported that cooking the rhizome prior to the dehydration process promoted gelatinization of the starch, facilitating and increasing dehydration rate of turmeric. The yield of ground turmeric on a wet basis ranged from 9.84 to $14.51 \mathrm{~g} / 100 \mathrm{~g}$ of the rhizome (Table 1). The significantly lower yield (Duncan test, $\mathrm{p} \leq 0.05$ ) observed for RNP (peeled and cooked in the retort) was expected since peel removal caused $30 \%$ mass loss. The moisture content of the ground sample ranged from 8.84 to $9.86 \mathrm{~g} / 100 \mathrm{~g}$. Higher moisture content was observed in control (C) samples and lower for RP and CW. According to Govindarajan (1980) and Sampathu et al. (1988), cooking facilitates water removal providing a product with lower moisture content. Since moisture content of ground turmeric obtained by the different treatments varied, the yield was also calculated on dry weight basis. Statistical analysis of the corrected values confirmed findings on wet basis.

Sieving the powder on 42 mesh resulted in yields of $58 \%$ in treatments involving cooking under immersion (CW and $\mathrm{CA}$ ), 61\% for the retorted turmeric without peel (RNP) and $65 \%$ for the sample retorted with the peel (RP) and for the sample without treatment (C). Such a difference in yield could be associated with the interference of the type of processing on the constituents of turmeric, which could have prevented the formation of small size particles during grinding. Gelatinized starch in the cooked turmeric could become viscoelastic and cause alteration on rheological properties, making it harder to grind and sieve after dehydration.

Moisture content of ground turmeric during storage. The moisture contents of ground turmeric during storage are indicated on Table 2. 
It can be observed that for every treatment, there was a significant increase in moisture content with storage time. Significantly higher levels were observed in 20 days storage for all treatments except for the one without peel (RNP) which showed significant difference on the $40^{\text {th }}$ day. These results suggest that the type of package used was not a good barrier to water vapor. According to Souza et al. (1997) the stability of curcuminoid pigments, in microcrystalline cellulose model system was not affected by water activity. Therefore, the change in moisture content with time would not affect pigment stability. However, during long term storage of ground turmeric, a better quality packing material should be used.

Table 2 - Moisture content of ground turmeric obtained by different treatments during storage

\begin{tabular}{|c|c|c|c|c|c|}
\hline \multirow{2}{*}{$\begin{array}{l}\text { Time } \\
\text { (days) }\end{array}$} & \multicolumn{5}{|c|}{ Moisture content $(\mathrm{g} / 100 \mathrm{~g}) /$ treatment $^{1}$} \\
\hline & $\mathrm{C}$ & RNP & $\mathrm{RP}$ & $\mathrm{CW}$ & $\mathrm{CA}$ \\
\hline 0 & $9.86 \pm 0.46^{\text {ay }}$ & $9.20 \pm 0.73^{\mathrm{abx}}$ & $8.93 \pm 0.51^{\mathrm{bw}}$ & $8.84 \pm 0.62^{b x}$ & $9.15 \pm 0.83^{\mathrm{abx}}$ \\
\hline 10 & $10.51 \pm 0.25^{\operatorname{axy}}$ & $9.93 \pm 0.79^{\mathrm{abwx}}$ & $9.35 \pm 0.43^{\mathrm{bw}}$ & $9.58 \pm 0.32^{\mathrm{bwx}}$ & $9.37 \pm 0.20^{\text {bwx }}$ \\
\hline 20 & $10.90 \pm 0.54^{\text {awx }}$ & $10.41 \pm 0.32^{\mathrm{abvw}}$ & $9.75 \pm 0.86^{\mathrm{bvw}}$ & $10.13 \pm 0.33^{\mathrm{bvw}}$ & $10.00 \pm 0.22^{\mathrm{bv}}$ \\
\hline 30 & $10.96 \pm 0.57^{\mathrm{avwx}}$ & $10.42 \pm 0.19^{\text {abvw }}$ & $9.62 \pm 0.82^{\mathrm{cvw}}$ & $10.08 \pm 0.57^{\text {bcrw }}$ & $10.19 \pm$ \\
\hline 40 & $11.54 \pm 0.21^{\mathrm{auvw}}$ & $10.97 \pm 0.48^{\text {abuv }}$ & $10.45 \pm 0.53^{\mathrm{bv}}$ & $10.45 \pm 0.55^{\text {buvw }}$ & $10.55 \pm 0.12^{b v}$ \\
\hline 50 & $12.15 \pm 0.10^{\text {auv }}$ & $11.05 \pm 0.30^{\text {buv }}$ & $10.47 \pm 0.79^{\mathrm{bv}}$ & $10.82 \pm 0.47^{\text {buv }}$ & $10.75 \pm 0.52^{b v}$ \\
\hline 60 & $12.24 \pm 0.46^{\mathrm{au}}$ & $11.53 \pm 0.35^{\mathrm{abu}}$ & $11.53 \pm 0.77^{\mathrm{abu}}$ & $11.04 \pm 0.24^{\mathrm{bu}}$ & $11.66 \pm 0.31$ \\
\hline
\end{tabular}

${ }^{\mathrm{T}} \mathrm{C}$ - control (no heat treatment); RNP - retort cooking with no peel; RP - retort cooking with peel; CW - cooking in water; CA cooking in alkaline water. Mean values ( \pm standard deviation) with the same superscript (abc) in the same line or (uvwxy) in the same column, do not differ statistically (Duncan test, $\mathrm{p} \leq 0.05$ ).

Levels of curcuminoid pigments during processing and storage of ground turmeric. The results obtained for curcuminoid pigments in ground turmeric after processing and during storage for 60 days indicated that processing affected significantly pigment levels, however no significant effect was observed with storage time. Therefore, all of the results, irrespective of the storage time, were taken into consideration for statistical analysis. As indicated on Figure 1, the ground turmeric obtained without heat treatment (C) was the one of worst quality with respect to curcuminoid pigments. The ones obtained by retort with skin (RP) and by immersion in alkaline media (CA) had intermediate quality. The best treatments were the ones submitted to retort without skin (RNP) and to immersion cooking (CW).

The content of pigments detected in the product obtained by alkaline cooking (CA) was $91 \%$ of that obtained by water cooking $(\mathrm{CW})$. Similar results were described by Sampathu et al. (1988). Reduction in pigment levels in samples cooked in alkaline media can be explained by curcuminoid pigments destruction in the presence of alkali at high temperatures, as described by Tonnesen \& Karlsen (1985a) and Price \& Buescher (1992). Results suggest that good quality ground turmeric can be obtained by cooking in plain water. A higher coefficient of variation was observed in control samples (2.3\%) compared to those submitted to cooking $(1.42-2.15 \%)$. Therefore, cooked turmeric shows higher uniformity or better pigment distribution. Govindarajan (1980) observed that cooking favors diffusion of pigments from cells to adjacent tissue, contributing to a better color homogenization. 


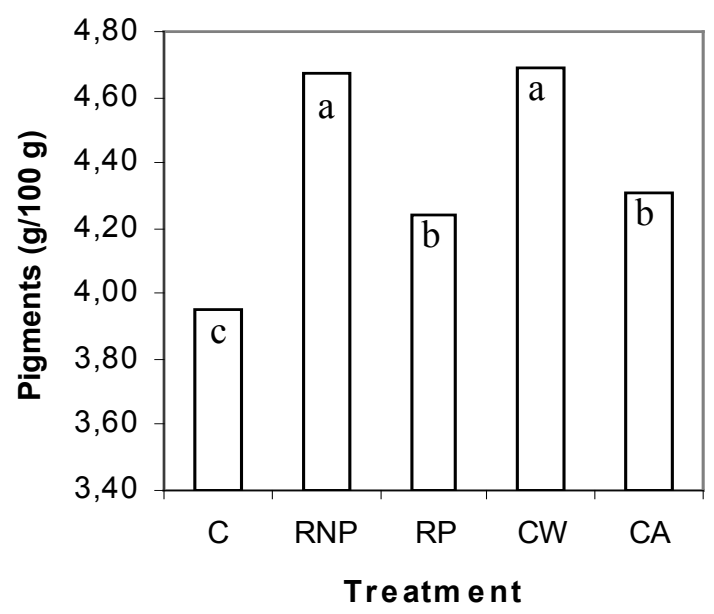

Figure 1 - Influence of rhizome treatment on curcuminoid pigment levels $(\mathrm{C}-$ control, no heat treatment; RNP - retort cooking with no peel; RP retort cooking with peel; $\mathrm{CW}$ - cooking in water; $\mathrm{CA}$ cooking in alkaline water. Mean values with the same letter do not differ statistically

(Duncan test, $\mathrm{p} \leq 0.05$ ).

Color characteristics of ground turmeric during processing and storage. The Hunter CIE color characteristics of ground turmeric obtained by different processes, expressed as $\mathrm{L}^{*} \mathrm{a}^{*}$ and $\mathrm{b}^{*}$, during storage for 60 days were also not affected by storage time. With respect to $\mathrm{L}-$ luminosity (Figure 2), the lower mean level was observed for treatment $\mathrm{C}$, indicating that this was the darkest product compared to the others (Duncan test, $\mathrm{p} \leq$ 0.05). It was followed by RP, with products obtained by RNP, CW and CA being the lightest ones. According to Govindarajan (1980), heat treatment of the rhizome prior to dehydration can inactivate oxidative enzymes, which could cause browning of the products. Another factor that could have caused darkening of ground turmeric is the occurrence of Maillard reaction. In the case of rhizomes submitted to immersion cooking $(\mathrm{CW}$ and CA), Maillard reaction could have been prevented due to the loss of soluble sugars in the cooking water. This could have limited the amount of sugars available for the reaction.

For $\mathrm{a}^{*}$ values, intensity of red (Figure 2), C samples were significantly lower than RP and CW. The sample CW did not differ significantly from CA. However both were lower than RNP (Duncan test, $p \leq 0.05$ ). These results indicate that, with removal of the peel, a product with higher intensity of red was obtained. In the absence of heat treatment $(\mathrm{C})$, a product with lower intensity of red was obtained.

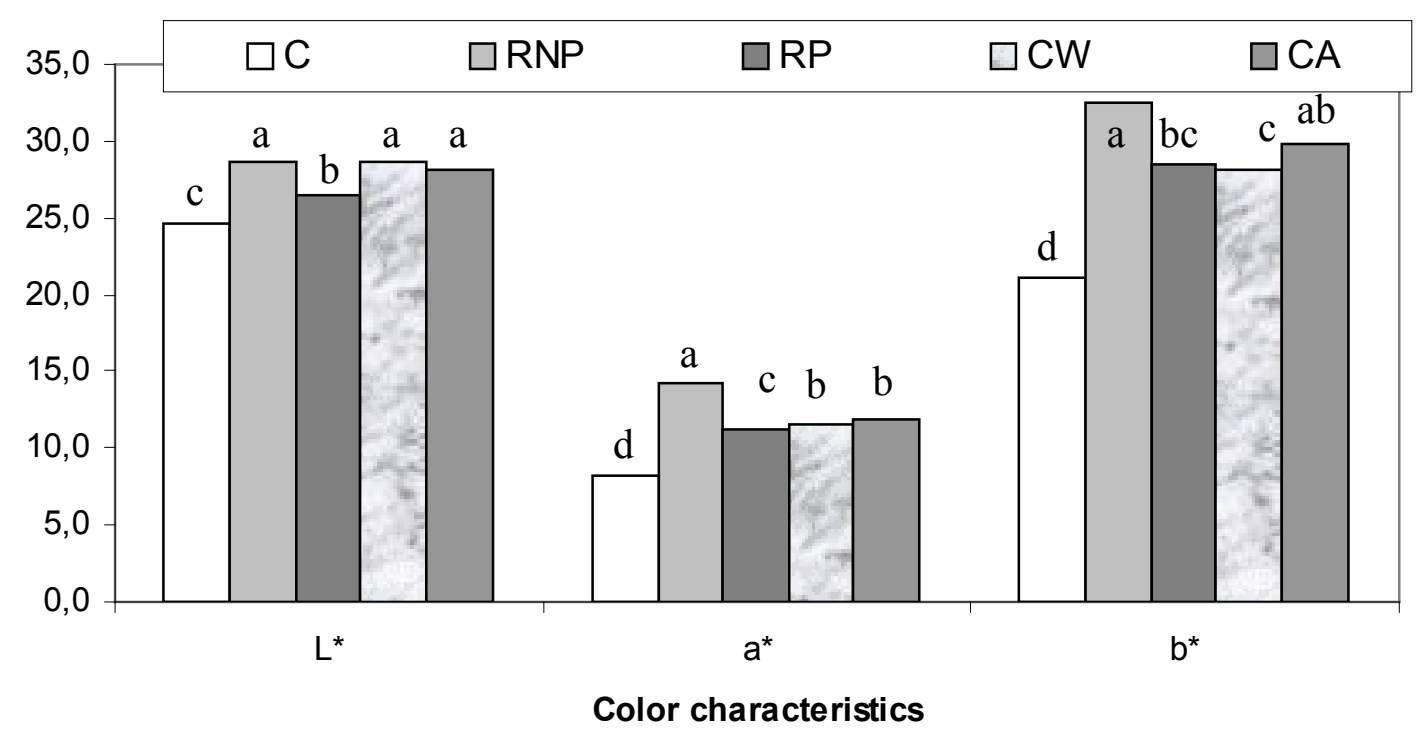

Figure 2 - Influence of processing on CIE Hunter $\mathbf{L}^{*}$ values for ground turmeric. (C - control, no heat treatment; RNP - retort cooking with no peel; RP - retort cooking with peel;CW - cooking in water; CA cooking in alkaline water. Mean values with the same letter do not differ statistically (Duncan test, $\mathrm{p} \leq 0.05$ ). 
Cooking in alkaline media did not affect intensity of red in ground turmeric compared to regular cooking. Results obtained for the intensity of yellow $-b^{*}$ value - are described on Figure 2.

Ground turmeric obtained by $\mathrm{C}$ presented lower intensity of yellow followed by CW and RP. The product retorted with peel (RP) did not differ significantly from the one cooked in alkaline media (CA), which did not differ from the RNP (Duncan test, $\mathrm{p} \leq 0.05$ ). These results indicate that cooking the sample prior to dehydration is important to obtain a product with higher intensity of yellow. Cooking in alkaline media (CA) affected the intensity of yellow compared to water cooking $(\mathrm{CW})$.

According to Tonnesen \& Karlsen (1985a), the presence of alkali at high temperatures could favor the formation of ferulic acid and of feruloilmethane. Part of the feruloilmethane formed during alkaline degradation can participate in condensation reactions originating compounds of yellow to yellow-brownish color, which could affect spectrophotometric determination of curcuminoid pigments. The removal of peel (RNP) also favored intensity of yellowness in ground turmeric.

Overall, the control sample (C) had the worst quality - lower pigment levels, lower intensity of yellow and red, and darker appearance. Removal of peel (RNP) and retort cooking (RP) provided a lighter product with higher pigment level and higher intensity of yellow and red. The product obtained by immersion cooking in water $(\mathrm{CW})$ was similar to RNP with respect to curcuminoid pigment. However, it had lower intensity of yellow and of red. The sample submitted to alkaline cooking (CA) was identical to RNP in luminosity and intensity of yellow, however contained lower pigment levels and lower intensity of red. This study indicates that processing can be optimized in order to obtain ground turmeric with desirable properties to satisfy different markets, such as a product with higher intensity of red for India and with higher intensity of yellow for other markets.

\section{CONCLUSIONS}

The removal of the peel from turmeric caused a mass loss of $30 \%$. However, the product obtained by this process had higher intensity of yellow and of red when compared to rhizome with peel. Heat treatment of turmeric prior to dehydration, reduced drying time, provided a powder with lower moisture content, higher levels of curcuminoid pigments and higher intensity of yellow and red compared to control. Cooking by immersion originated a product of superior quality compared to the one cooked in retort with respect to curcuminoid pigments and luminosity $-L^{*}$ value. Significant difference was detected in the intensity of red $\left(a^{*}\right)$ and of yellow $\left(b^{*}\right)$. Cooking in alkaline media provided a product with lower pigment levels and higher intensity of yellow $\left(b^{*}\right)$ compared to regular cooking. During storage of ground turmeric for sixty days, no significant difference was observed on curcuminoid pigments levels and CIE Hunter color characteristics $\left(L^{*} a^{*}\right.$ $\left.b^{*}\right)$. Polyethylene bags were not a good barrier to water vapor, allowing absorption of moisture by the ground turmeric during storage.

\section{ACKNOWLEDGEMENTS}

The authors acknowledge EMATER, Patos de Minas and Belo Horizonte, State of Minas Gerais, Brazil for providing turmeric rhizomes and Rosa Junqueira from Laboratório de Colorimetria, Setor de Tecnologia Metalúrgica, CETEC for the use of HunterLab ColorQuest II.

\section{RESUMO}

A influência do processamento no rendimento e na qualidade da cúrcuma em pó foi investigada. Os rizomas foram descascados, cozidos (autoclave ou imersão) em água ou meio alcalino, fatiadas, desidratadas, moídas, peneiradas, embaladas em polietileno e armazenadas por 60 dias à temperatura ambiente. O rendimento variou de 9,84 a $14,51 \mathrm{~g}$ de pó/100 g de rizoma com teores de umidade de 8,84 a $9,86 \mathrm{~g} / 100 \mathrm{~g}$. A remoção da casca causou perda de $30 \%$ de massa mas o pó obtido apresentou maior intensidade de amarelo e vermelho. O cozimento causou uma redução no tempo de secagem e forneceu um pó com menor teor de umidade, maiores teores de pigmentos curcuminóides e maiores valores de Hunter CIE $L^{*}, a^{*}$ e $b^{*}$. O cozimento por imersão forneceu um pó de melhor qualidade comparado àquele por autoclave. $\mathrm{O}$ uso de meio alcalino resultou em um 
produto com menor teor de pigmentos curcuminóides, e maior intensidade de amarelo. Não foi observada alteração nos teores de pigmentos e nas características de cor do pó durante armazenamento.

\section{REFERENCES}

Gomes, F. P. (1990), Curso de estatística experimental. 13. ed. São Paulo : Nobel. 467 pp.

Govindarajan, V. S. (1980), Turmeric - chemistry, technology and quality. CRC Critical Reviews Food Science and Nutrition, 12 : (3), 199-301.

Goyal, R. K. and Korla, B. N. (1993), Changes in the quality of turmeric rhizomes during storage. Journal of Food Science and Technology, 30(5), 362-364.

Guimarães, I. S. S. (1987), Corantes naturais vermelhos e amarelos. In: Simpósio sobre aditivos para alimentos. Campinas : ITAL. pp. 2.

Hallagan, J. B.; Allen, D. C. and Borzelleca, J. F. (1995), The safety and regulatory status of food, drug and cosmetics colour additives exempt from certification. Food Chemical Toxicology, 33: (6), 515-528.

Mafart, P. (1991), Ingenieria Industrial Alimentaria. Zaragoza. Procesos Fisicos de Conservacion. Acribia, 1, 81-95.

Nunes, F. V. (1989), Cultivo da cúrcuma é fácil e lucrativo. Manchete Rural, 29, 60.

Osawa, T.; Sugiyama, Y.; Inayoshi, M. and Kawakishi, S. (1995), Antioxidative activity of tetrahydro-curcuminoids. Bioscience Biotechnology Biochemistry, 59, 1609-1612.

Price, L. C. and Buescher, R. W. (1992), Turmeric pigments: stability characteristics and reaction mechanism of photoxidation and alkaline degradation. In: IFT 92 Annual Meeting Food Expo. New Orleans. pp. 376.

Sampathu, S. R.; Krishnamurthy, N.; Sowbagya, H. B. and Shankarana-Rayana, M. L. (1988), Studies on quality of turmeric (Curcuma longa L.) in relation to curing methods. Journal of Food Science and Technology, 25 : (3), 152-155.

Semwal, A. D., Sharma, G. K. and Arya, S. S. (1997), Antioxygenic activity of turmeric (Curcuma longa) in sunflower oil and Ghee. Journal of Food Science and Technology, 34 : (1), 67-69.

Souza, C. R. A. and Glória, M. B. A. (1998), Chemical analysis of turmeric from Minas Gerais, Brazil and comparison of methods for flavor free oleoresin. Brazilian Archives of Biology and Technology, 41: (2), 218-224.

Souza, C. R. A.; Osme, S. F. and Glória, M. B. A. (1997), Stability of curcuminoid pigments in model systems. Journal of Food Processing and Preservation, 21 : (5), 353-363.
Srinivasan, K.; Sambaiah, K. and Chandrasekhara, N. (1992), Loss of active principles of common spices during domestic cooking. Food Chemistry, 43, 271-274.

Takahashi, M. Y. (1987), Monografias de corantes naturais para fins alimenticios: padrões e identidade. 2.ed. São Paulo : Instituto Adolfo Lutz. 118 pp.

Tonnesen, H. H. and Karlsen, J. (1985a), Studies on curcumin and curcuminoids. V. Alkaline degradation of curcumin. Zournal Lebensmittel Forschung, 180 : (2), 132-134.

Tonnesen, H. H. and Karlsen, J. (1985b), Studies on curcumin and curcuminoids. VI. Kinectics of curcumin degradation in aqueous solution. Zournal Lebensmittel Forschung, 180 : (5), 402-404.

Received: August 24, 2000; Revised: September 24, 2001; Accepted: January 18, 2002. 